\title{
Small Firms, Corruption, and Demand for Credit. Evidence from the Euro Area ${ }^{1}$
}

\author{
Emma Galli ${ }^{1}$, Danilo V. Mascia ${ }^{2}$, Stefania P. S. Rossi ${ }^{3}$ \\ ${ }^{1}$ Department of Social and Economic Sciences, Sapienza University of Rome, Italy \\ ${ }^{2}$ Department of Economics and Business, The University of Cagliari, Italy \\ ${ }^{3}$ Department of Economics, Business, Mathematics and Statistics, The University of Trieste, Italy \\ Correspondence: Emma Galli, Department of Social and Economic Sciences, Sapienza University of Rome, \\ Piazzale Aldo Moro 5, 00185 Roma, Italy.
}

Received: September 6, 2017

Accepted: October 7, $2017 \quad$ Online Published: October 18, 2017

doi:10.5539/ibr.v10n11p158

URL: https://doi.org/10.5539/ibr.v10n11p158

\begin{abstract}
In this paper, we aim to assess how the quality of the institutional environment - identified according to the level of corruption perceived in a country - may affect the access to credit for micro, small, and medium-sized enterprises (MSMEs). Based on a sample of 68,115 observations - drawn from the ECB-SAFE survey - related to MSMEs chartered in 11 euro area countries, we investigate whether the level of corruption affects their demand for bank loans during the period 2009-2014.

Overall, we find that the degree of corruption seems to play a role in the applications for bank loans when small firms are under investigation. Interestingly, results highlight that small businesses chartered in highly corrupt countries face a greater probability of self-restraint regarding their loan applications (about 7.4\%) than small firms located in low-corruption economies (around 6\%). The results are robust to various model specifications and econometric methodologies. Our findings suggest that anti-corruption policies and measures enhancing transparency in the economy may be crucial in reducing the negative spillovers generated by a low-quality institutional environment on the access to credit by small firms.
\end{abstract}

Keywords: credit access, bank loans, MSMEs, corruption

JEL Classifi cation: G20, G21, G30, G32, D73

\section{Introduction}

Bank credit is a crucial financing tool for the development of micro, small, and medium-sized enterprises (MSMEs), given their difficulties in easily entering the equity markets (Ayadi and Gadi 2013; Kremp and Sevestre 2013; Vermoesen, Deloof, and Laveren 2013). However, the access to bank credit is not as easy as one might think. Specifically, MSMEs often come into trouble when they have to provide good collateral for the loan officers (Cowan, Drexler, and Yañez 2015; Öztürk and Mrkaic 2014; Vos et al. 2007). Additionally, in times of crisis - like the one that recently occurred in Europe - liquidity shortages and credit restrictions have further weakened the access to bank loans for MSMEs (Popov and Van Horen 2015; Popov and Udell 2012). This is not inconsequential, given that MSMEs are important drivers of the European economy. Indeed, they represent $99 \%$ of nonfinancial firms in the European Union (EU), provide jobs for more than 91 million people $(67 \%$ of

\footnotetext{
${ }^{1}$ An earlier version of this paper appears as ADBI Working Paper Series, No. 756 July 2017.

We thank the editor and the anonymous referee for their comments. A preliminary version of this paper was presented at the ADBI workshop on 'MSMEs' Access to Finance in a Digital Finance Era" in Tokyo, Japan, in October 2016; at the 57th Annual Conference of the Italian Economic Association in Milan, Italy, in October 2016; and at the World Finance \& Banking Symposium in Dubai, UAE, in December 2016. We are grateful to the discussants and the numerous participants for their useful comments and suggestions. We also thank the ECB for the use of data from the Survey on the Access to Finance of Enterprises. Additionally, Danilo V. Mascia and Stefania P.S. Rossi gratefully acknowledge the research grant from the Autonomous Region of Sardinia, Legge Regionale 2007, N. 7 [Grant Number CRP-59890, year 2012].
} 
employment in the EU), and generate about $60 \%$ of the total added value of the entire Union (EIF, 2016).

Apart from the firm financial features and the economic context in which they operate, the quality of the institutional environment may play an important role in affecting the credit market in many regards.

While a vast branch of the empirical literature has shown that the efficiency of institutions, the enforcement of legal rights - i.e., creditor rights protection and judicial enforcement (La Porta et al. 1997; Qian and Strahan 2007; Djankov et al. 2008; Moro, Maresch, and Ferrando 2016; Galli, Mascia, and Rossi 2017) - and the competitiveness of the bank market (Cavalluzzo, Cavalluzzo, and Wolken 2002) play a role in the credit market, thereby affecting MSMEs' loan applications, scarce attention has been devoted in literature to the relation between corruption and firms financing. This is particularly unfortunate given that corruption is considered one of the major obstacles to economic growth. ${ }^{2}$

To the best of our knowledge, the literature still lacks of empirical contributions regarding the effect that corruption has on the access to bank credit by MSMEs. To fill this gap, the present study aims at assessing how the level of corruption may affect the MSMEs access to bank credit. Specifically we assume that corruption will modify the firms' expectations about their bank financing and the level of trust required in the bank-firm relationship. Consequently, the hypothesis under investigation is the following:

$\mathrm{H}_{1}$ : In a more corrupt institutional context, MSMEs face a higher probability to self-refrain from applying to bank loan anticipating more difficulties in the bank-firm relationship, than larger firms.

To test our hypothesis we employ two different specifications. First we estimate the probability to self-refrain for MSMEs, compared to larger firms, by controlling for alternative measures of corruption, as well as for a large set of firm-level characteristics and macro firm-invariant indicators. Second, we consider only the discouraged borrowers (i.e., those that do not apply to bank loan for fear of rejection), and we study the relationship between corruption and MSMEs by interacting the variable "small" firms with corruption measures. Finally, to corroborate our results and to control for the selection bias we propose several econometric strategies (multinomial logit, logit and Heckman models).

Our empirical analysis is based on a sample of 68,115 observations - drawn from the ECB Survey on the Access to Finance of Enterprises (SAFE) - related to MSMEs chartered in 11 euro area countries during the period 2009-2014 (i.e., from the first to the twelfth wave of the survey).

Our results, robust to different specifications and empirical techniques, show that the quality of the institutional environment, proxied by the level of corruption, matters in affecting the micro and small firms' applications for bank loans.

The rest of paper is organized as follows. In Section 2, we briefly report the related literature. Section 3 illustrates the data and the methodology. In Section 4, we discuss the steps of our empirical strategy and comment on the results. Section 5 draws some conclusions.

\section{Related Literature}

Corruption, defined as the abuse by a public officer of his/her power to obtain a private gain (Rose-Ackerman 1975), is a complex and severe phenomenon that is differently spread in industrialized, emerging and de veloping countries. Most of the economic literature and institutional reports consider corruption as a major obstacle to social development and economic growth - namely, the so-called hypothesis of "sand in the wheels" (see, among others, Myrdal 1989; Andvig and Moene 1990; Shleifer and Vishny 1993; Mauro 1995; Keefer and Knack 1997; Hall and Jones 1999; La Porta et al. 1999; Li, Xu, and Zou 2000; Gyimah-Brempong 2002; Tanzi and Davoodi 2002; Kaufmann 2005; Blackburn and Sarmah 2008; World Bank 2007; World Bank various years). ${ }^{3}$ According to this hypothesis, corruption acts as a barrier to competition, reduces the incentives to invest both domestically and from abroad, misallocates public resources negatively affecting the efficiency of public investments (Mauro 1998; Tanzi and Davoodi 1998; Gupta et al. 2001), and lowers the level of trust in the institutions (Hunt 2005; Hunt and Laszlo 2005). As a consequence, corruption generates harmful effects on both the social development and the economic growth of a country.

\footnotetext{
${ }^{2}$ For a recent survey, see Dimant and Tosato (2017).

${ }^{3}$ On the contrary, another strand of literature develops the so-called "grease the wheels" hypothesis arguing that corruption represents the market response to the inefficiencies of the public sector. This literature empirically predicts a non-linear relation between corruption and economic growth at low le vels of corruption incidence (see, among others, Lui 1985; Klitgaard 1988; Acemoglu and Verdier 1998; Shleifer and Vishny 1993).
} 
Most importantly to our purpose, corruption negatively affects the business environment, diminishing the level of horizontal and vertical trust and producing uncertainty. Some papers (e.g., Bhagwati 1982; Campos, Estrin, and Proto 2010; Svensson 2003) have emphasized that in a highly corrupt environment, bribes represent a barrier to entry especially for MSMEs, because the scarcity of their financial resources, the lower bargaining power, and the difficulty in accessing bank credit make it very difficult for them to refuse the payment of bribes. In other words, the burden per output is obviously greater for MSMEs than for the large companies and multinationals (Gbetnkom 2012; Seker and Yang 2012).

With respect to this issue, a related strand of the literature focuses on the role of social capital in the credit market that supposedly stimulates the opposite mechanisms. By increasing the level of trust and reducing the asymmetric information characterizing credit contracts, social capital improves the credit conditions for firms thereby easing their access to bank loans (Uzzi 1999; Guiso, Sapienza, and Zingales 2004; Moro and Fink 2013; Mistrulli and Vacca 2014) - and facilitates the collection of soft information, which in turn reduces adverse selection and moral hazard phenomena.

\section{Data and Methodology}

\subsection{Data Description}

Most of the data that we use in the paper comes from the SAFE, which is jointly run by the European Central Bank (ECB) and the European Commission (EC) and has been conducted every six months since 2009 with the aim of collecting economic and financial information about European MSMEs. Each wave of the survey is addressed to a randomly selected sample of nonfinancial enterprises from the Dun \& Bradstreet business register; firms in agriculture, public administration, and financial services, however, are deliberately excluded.

We conduct our tests on a subsample of enterprises chartered in the 11 largest euro area economies (i.e., Austria, Belgium, France, Finland, Germany, Greece, Italy, Ireland, the Netherlands, Portugal, and Spain), where the differences in the micro and macroeconomic features, as well as in the socio-institutional environment, are relevant.

All the macrodata that we employ as control variables in our regressions are retrieved from different sources (i.e., Heritage Foundation, Worldwide Governance Indicators, OECD, ECB Data Warehouse, World Bank).

Therefore, our sample consists of 68,115 firm observations and is stratified by country, firm size, and activity. Table 1.a shows the distribution of our observations by country, with France, Germany, Spain, and Italy exhibiting the highest sample representativeness. Table 1.b, on the other hand, displays the distribution of our sample observations by firm size.

Table 1. a. Observations by Country

\begin{tabular}{lcc}
\hline & Country Name & Observations \\
\cline { 2 - 3 } & Freq. & \% \\
\hline Austria & 4,101 & 6.02 \\
Belgium & 4,075 & 5.98 \\
Finland & 3,787 & 5.56 \\
France & 9,991 & 14.67 \\
Germany & 9,950 & 14.61 \\
Greece & 4,088 & 6.00 \\
Ireland & 3,708 & 5.44 \\
Italy & 9,930 & 14.58 \\
Netherlands & 4,239 & 6.22 \\
Portugal & 4,288 & 6.30 \\
Spain & 9,958 & 14.62 \\
\hline Total & 68,115 & 100.00 \\
\hline
\end{tabular}


Table 1. b. Observations by Firm Size

\begin{tabular}{lrr}
\hline & \multicolumn{2}{c}{ Observations } \\
\cline { 2 - 3 } \multicolumn{1}{c}{ Firm Size } & Freq. & \% \\
\hline Micro (up to 9 employees) & 22,921 & 33.65 \\
Small (between 10 and 49 employees) & 22,730 & 33.37 \\
Medium (between 50 and 249 employees) & 17,287 & 25.38 \\
Large (more than 250 employees) & 5,177 & 7.60 \\
Total & 68,115 & 100.00 \\
\hline
\end{tabular}

3.2 Dependent and Key Variables

In order to assess whether corruption affects the access to bank credit of small firms, we employ question "q7a_a" of the survey as a dependent variable. In particular, the question is aimed at detecting whether a firm applied for bank loans, and if not, the reasons why it did not. More specifically, the question is:

[With regards to bank loans], "could you please indicate whether you: (1) applied for any over the past 6 months; (2) did not apply because you thought you would be rejected; (3) did not apply because you had sufficient internal funds; or (4) did not apply for other reasons"

The values from 1 to 4, outlined in parentheses, represent the way each respondent's answers were coded.

In the second stage of our investigation, we employ a dummy called Fear as a dependent variable. This dummy is generated by utilizing information from answer (2) of the above-mentioned question q7a_a - hence taking a value of one when an enterprise did not apply for fear of rejection, and zero when a firm did not apply for other reasons.

Then we identify two key variables for our analyses, namely the size of the firm and the country's level of corruption. The former is measured with a dummy (Small) that is equal to one when a firm has fewer than 50 employees, and zero otherwise. As regards the latter, it is worth noting that the literature recognizes a variety of measures that proxy for corruption: perception-based indicators, experience-based indicators, and objective measures such as the number of corruption-related trials or cases (Gutmann, Padovano, and Voigt 2014). In this paper, we decide to employ two alternatively comparable survey measures, namely Freedom from corruption (drawn from the Heritage Foundation) - whose score is primarily derived from Transparency International's Corruption Perception Index (CPI) - and Control of corruption (Worldwide Governance Indicators), which are both available for all the countries of our sample and on a yearly basis.

With regards to firm size, Figure 1 reports the percentage of small firms in our sample, by country. Interestingly, we note that in Belgium, Finland, Greece, and Ireland small firms cover more than $75 \%$ of all firm observations.

Figure 2 and Figure 3, on the other hand, show the average value of the two corruption indicators employed in our analyses, by country. For the sake of clarity, please note that the higher (lower) the value shown for each indicator, the lower (higher) the level of corruption in that country.

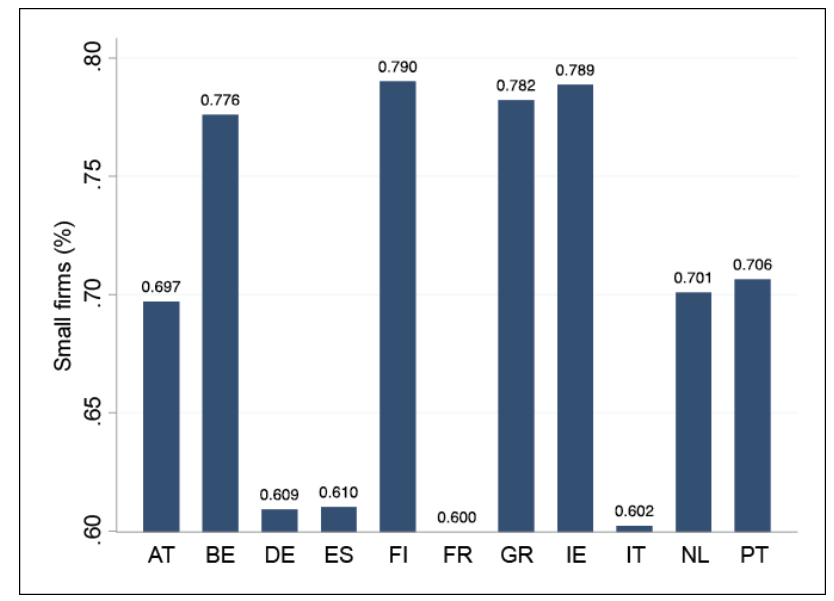

Figure 1. Percentage of Small Firms by Country

$\mathrm{AT}=$ Austria, $\mathrm{BE}=$ Belgium, $\mathrm{DE}=$ Germany, $\mathrm{ES}=$ Spain, $\mathrm{FI}=$ Finland, $\mathrm{FR}=$ France , $\mathrm{GR}=$ Greece, $\mathrm{IE}=$ Ireland, $\mathrm{IT}=$ Italy, $\mathrm{NL}=$ The Netherlands, $\mathrm{PT}=$ Portugal . 


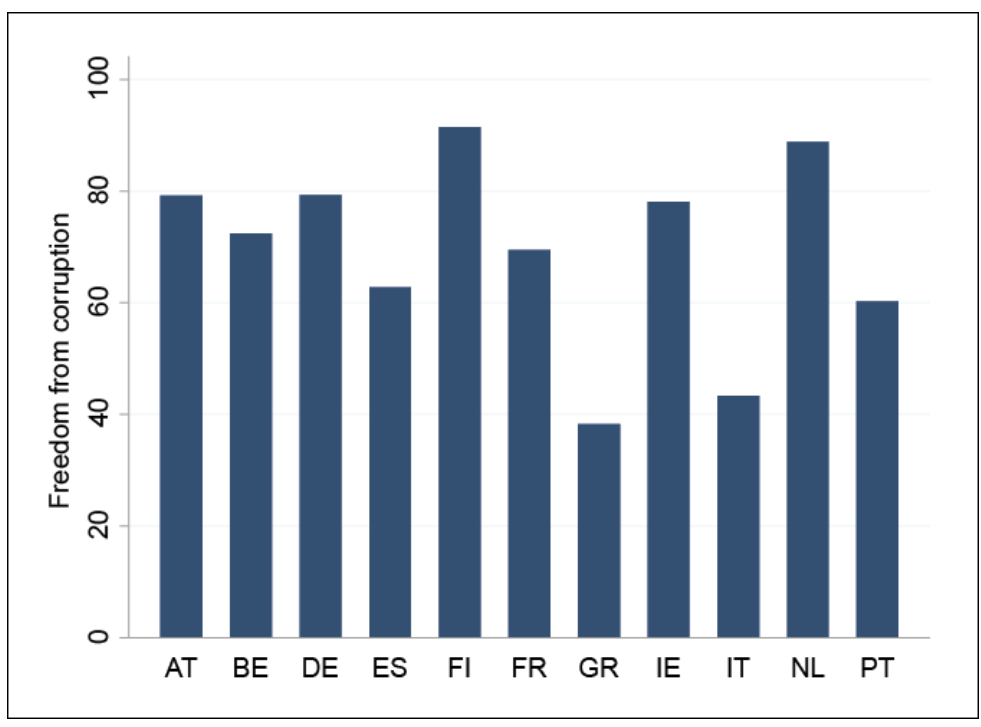

Figure 2. Freedom from Corruption by Country

$\mathrm{AT}=$ Austria, $\mathrm{BE}=$ Belgium, $\mathrm{DE}=$ Germany, $\mathrm{ES}=$ Spain, $\mathrm{FI}=$ Finland, $\mathrm{FR}=$ France, $\mathrm{GR}=$ Greece, $\mathrm{IE}=$ Ireland, $\mathrm{IT}=$ Italy, $\mathrm{NL}=$ The Netherlands, $\mathrm{PT}=$ Portugal .

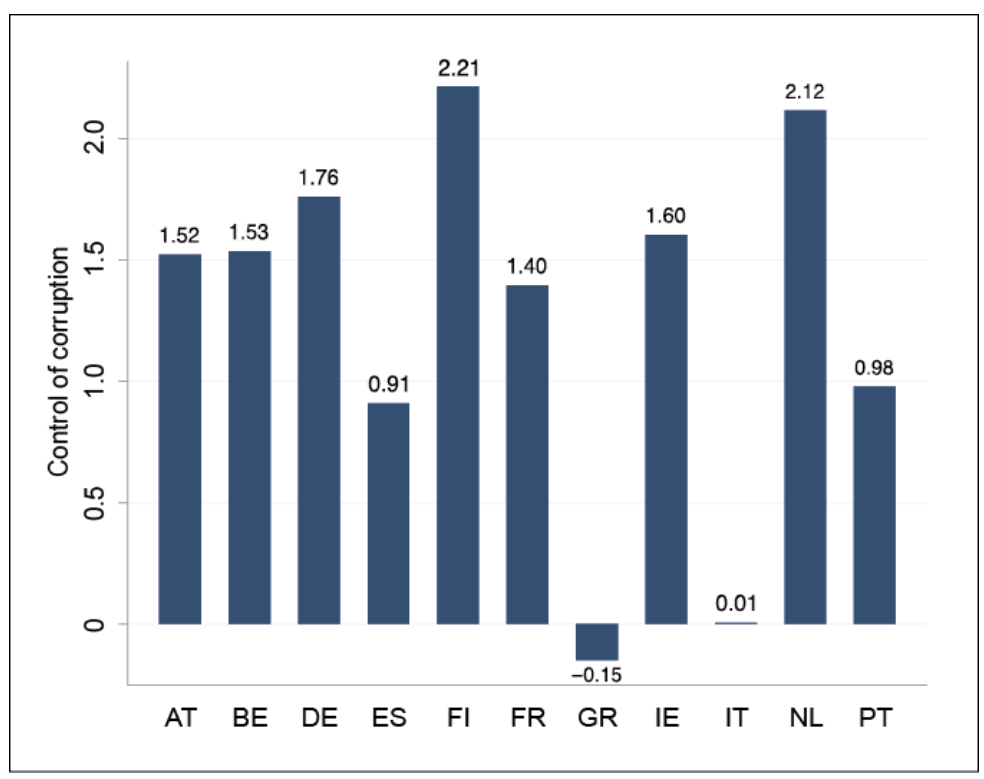

Figure 3. Control of Corruption by Country

$\mathrm{AT}=$ Austria, $\mathrm{BE}=$ Belgium, $\mathrm{DE}=$ Germany, $\mathrm{ES}=$ Spain, $\mathrm{FI}=$ Finland, $\mathrm{FR}=$ France, $\mathrm{GR}=$ Greece, $\mathrm{IE}=$ Ireland, $\mathrm{IT}=$ Italy, $\mathrm{NL}=$ The Netherlands, $\mathrm{PT}=$ Portugal .

Finally, Figure 4 depicts a picture of the level of corruption in the euro area through the use of a map. More specifically, based on the "Freedom from corruption" indicator, we assign different colors to the countries in our sample according to their perceived degree of corruption. In particular, we employ the following scale of colors to highlight the territories from the most to the least corrupt ones: red, orange, yellow, light green, and dark green. For instance, countries in red (i.e., Greece and Italy) represent the most corrupt economies. In contrast, areas in dark green (i.e., Finland and the Netherlands) are the least corrupt ones. 


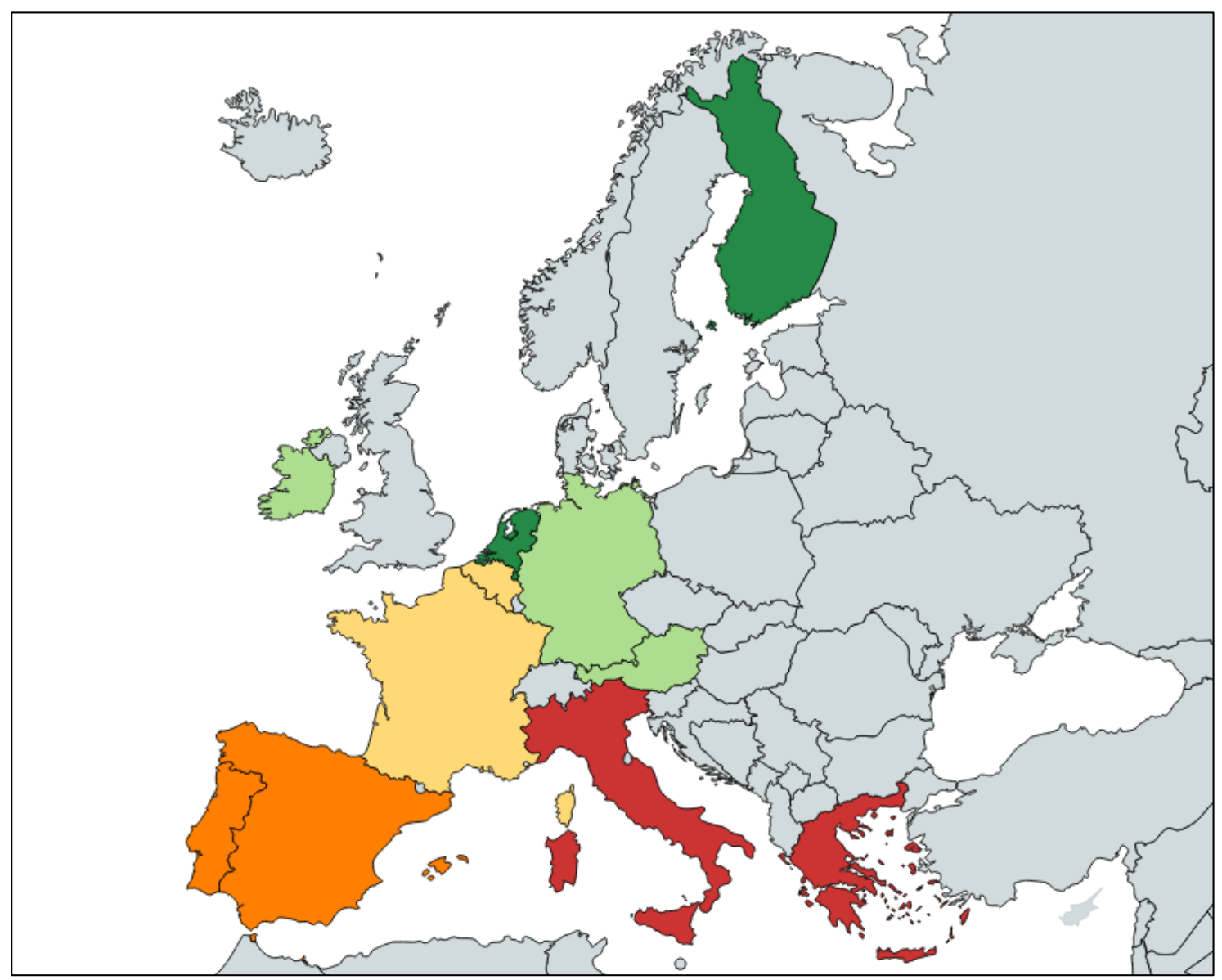

Figure 4. Map Depicting the Degree of Corruption in our Sample

Source $=$ Map customized by the authors, according to the degree of corruption provided by the Heritage Foundation.

\subsection{Econometric Strategy and Control Variables}

For testing our hypothesis [H1], we model the probability of applying for bank loan for the $i$-th firm with the following specification [1]:

$\mathrm{P}_{\mathrm{i}}$ (applying for loans $)=\mathrm{f}$ (small firms, corruption, firm controls, macro controls, country, wave $)$

Small firms and corruption are the key variables in our model. The vector "firm controls" include both standard firm characteristics, such as age (very recent, recent and old), sector (construction, manufacturing, wholesale) and financial firm controls, such as changes (up and down) in le verage, in capital, in profitability, and in credit history of the $i$-th firm. The macro controls include GDP growth, the Herfindahl Index (HI) of bank concentration, Non-performing loans over gross loans (NPL ratio), and a dummy that captures the expansionary monetary policy phase that followed the Outright Monetary Transaction (OMT) announcement by the ECB. Finally, we use country and time dummies as additional controls. 
Table 2. Summary Statistics

\begin{tabular}{|c|c|c|c|c|c|c|}
\hline & Observations & Mean & Median & St. Dev. & p1 & p99 \\
\hline \multicolumn{7}{|l|}{ Dependent variables } \\
\hline q7a_a & 68,115 & 2.626 & 3.000 & 1.094 & 1.000 & 4.000 \\
\hline Fear & 50,096 & 0.083 & 0.000 & 0.276 & 0.000 & 1.000 \\
\hline \multicolumn{7}{|l|}{ Key variables } \\
\hline Small & 68,115 & 0.670 & 1.000 & 0.470 & 0.000 & 1.000 \\
\hline Freedom from corruption & 68,115 & 67.588 & 69.000 & 15.489 & 34.000 & 94.000 \\
\hline Control of corruption & 68,115 & 1.187 & 1.420 & 0.712 & -0.250 & 2.220 \\
\hline \multicolumn{7}{|l|}{ Country-level controls } \\
\hline GDP Growth & 68,115 & -0.620 & 0.050 & 2.934 & -8.200 & 5.050 \\
\hline Concentration & 68,115 & 0.088 & 0.060 & 0.077 & 0.021 & 0.370 \\
\hline NPL & 68,115 & 7.101 & 4.295 & 6.254 & 0.500 & 31.899 \\
\hline OMT & 68,115 & 0.437 & 0.000 & 0.496 & 0.000 & 1.000 \\
\hline \multicolumn{7}{|l|}{ Firm-level controls } \\
\hline Profit up & 68,115 & 0.238 & 0.000 & 0.426 & 0.000 & 1.000 \\
\hline Profit down & 68,115 & 0.472 & 0.000 & 0.499 & 0.000 & 1.000 \\
\hline Credit up & 68,115 & 0.204 & 0.000 & 0.403 & 0.000 & 1.000 \\
\hline Credit down & 68,115 & 0.142 & 0.000 & 0.349 & 0.000 & 1.000 \\
\hline Capital up & 68,115 & 0.243 & 0.000 & 0.429 & 0.000 & 1.000 \\
\hline Capital down & 68,115 & 0.204 & 0.000 & 0.403 & 0.000 & 1.000 \\
\hline Leverage up & 68,115 & 0.207 & 0.000 & 0.405 & 0.000 & 1.000 \\
\hline Leverage down & 68,115 & 0.276 & 0.000 & 0.447 & 0.000 & 1.000 \\
\hline Demand up & 68,031 & 0.191 & 0.000 & 0.393 & 0.000 & 1.000 \\
\hline Demand down & 68,031 & 0.131 & 0.000 & 0.337 & 0.000 & 1.000 \\
\hline Very recent & 68,115 & 0.020 & 0.000 & 0.139 & 0.000 & 1.000 \\
\hline Recent & 68,115 & 0.069 & 0.000 & 0.253 & 0.000 & 1.000 \\
\hline Old & 68,115 & 0.128 & 0.000 & 0.334 & 0.000 & 1.000 \\
\hline Construction & 68,115 & 0.100 & 0.000 & 0.300 & 0.000 & 1.000 \\
\hline Manufacturing & 68,115 & 0.255 & 0.000 & 0.436 & 0.000 & 1.000 \\
\hline Wholesale/Retail & 68,115 & 0.337 & 0.000 & 0.473 & 0.000 & 1.000 \\
\hline
\end{tabular}

We perform our analysis in three steps. First we estimate equation [1] by employing a multinomial logit model as in Demirguc-Kunt, Klapper, and Singer (2013) and Badoer and James (2016), because: $i$ ) our dependent variable is a discrete one, given that it takes more than two outcomes and the outcomes have no natural ordering (see description in Section 3.2); ii) it is suitable for the use of continuous variables and multiple categorical variables as regressors.

Second, we test model [1] by employing our Fear dummy (which captures the discouraged borrowers) as a dependent variable through the use of logit models, and further corroborate our findings with a series of robustness checks that we carry out via Heckman selection models. Additionally, to study the relation between the discouraged MSMEs and corruption, we interact the dummy Small (which captures small firms) with the two alternative measures of corruption.

Finally, we repeat our multinomial logit estimations by splitting the sample into low- and high-corruption countries in order to check whether the behavior of small firms changes according to the level of a country's corruption.

All regressions include time and country dummies. Calibrated weights are employed to adjust the sample to be representative of the population (as in Ferrando, Popov, and Udell 2017). Standard errors are corrected for heteroskedasticity, and clustered at the country-level, to remove possible bias in the estimations.

Table 2 shows the summary statistics of the variables employed in our analysis. Table A1 in the Appendix, meanwhile, provides descriptions of variables and sources.

\section{Empirical Results}

\subsection{Multinomial Logit Models - Full Sample}

The empirical results of our estimations regarding the likelihood that small firms will apply for bank loans are presented in Table 3. Following the assumptions of the multinomial logit methodology, here we set the first answer to question q7a_a (i.e., "applied") as our base outcome. Panel A (B) reports the estimate of model [1] when controlling for corruption as proxied by Freedom from corruption (Control of corruption). Estimated 
marginal effects are reported in brackets.

Overall, we see that - after having controlled for a wide set of firm characteristics - small firms are about $6.5 \%$ more likely than their larger counterparts to refrain from applying for bank loans due to fear of rejection (Column 2). Interestingly, we also note that the two proxies for corruption show a negative and significant coefficient - thereby signaling that a lower level of corruption in a country translates into a lower probability of refraining from applying for fear of rejection. In other words, our result anticipates that the share of discouraged borrowers should be lower when the quality of the economic environment is higher (i.e., when the degree of corruption is low).

Table 3. Bank Loan Applications: Multinomial Logit Model

\begin{tabular}{|c|c|c|c|c|}
\hline & (1) & (2) & (3) & (4) \\
\hline & Applied & $\begin{array}{l}\text { Did_not_apply } \\
\text { _fear }\end{array}$ & $\begin{array}{l}\text { Did_not_apply } \\
\text {__suff }\end{array}$ & $\begin{array}{l}\text { Did_not_apply } \\
\text { _other }\end{array}$ \\
\hline \multicolumn{5}{|l|}{ PanelA } \\
\hline Small & (base) & $\begin{array}{l}1.034 * * * \\
(0.08) \\
{[0.064]}\end{array}$ & $\begin{array}{l}0.363 * * * \\
(0.08)\end{array}$ & $\begin{array}{l}0.528 * * * \\
(0.07)\end{array}$ \\
\hline $\begin{array}{l}\text { Freedom } \\
\text { Corruption }\end{array}$ & & $\begin{array}{l}-0.079 * * \\
(0.03)\end{array}$ & $\begin{array}{l}-0.025^{* * *} \\
(0.01)\end{array}$ & $\begin{array}{l}-0.009 \\
(0.01)\end{array}$ \\
\hline SAFE Controls & YES & YES & YES & YES \\
\hline Observations & 68,115 & 68,115 & 68,115 & 68,115 \\
\hline Pseudo R-squared & 0.0752 & 0.0752 & 0.0752 & 0.0752 \\
\hline \multicolumn{5}{|l|}{ Panel B } \\
\hline Small & (base) & $\begin{array}{l}1.031 * * * \\
(0.08) \\
{[0.065]}\end{array}$ & $\begin{array}{l}0.361 * * * \\
(0.08)\end{array}$ & $\begin{array}{l}0.527 * * * \\
(0.07)\end{array}$ \\
\hline Control of Corruption & & $\begin{array}{l}-1.764 * \\
(0.96)\end{array}$ & $\begin{array}{l}-0.746^{* * * *} \\
(0.22)\end{array}$ & $\begin{array}{l}-0.893 * * \\
(0.35)\end{array}$ \\
\hline SAFE Controls & YES & YES & YES & YES \\
\hline Observations & 68,115 & 68,115 & 68,115 & 68,115 \\
\hline Pseudo R-squared & 0.0749 & 0.0749 & 0.0749 & 0.0749 \\
\hline
\end{tabular}

Note: This table shows regression results of the multinomial logit model regarding the likelihood that small firms do not apply for bank loans. The dependent variable -as described in Section 3.2 - equals $1 / 2 / 3 / 4$ if a firm applied/did not apply because of possible rejection/did not apply because of sufficient internal funds/did not apply for other reasons during the past six months, respectively. Small is a dummy that equals one if the firm has fewer than 50 employees, and zero otherwise. Regressions control for Freedom from corruption (Control of corruption) in Panel A (B). Though not showing, both specifications include a wide set of firm-level characteristics. See Table A1 in the Appendix for all variable definitions and sources. All regressions use sampling weights that adjust the sample to be representative of the population. Additionally, all regressions include time and country dummies. Heteroskedasticity-robust standard errors, clustered at the country level, appear in parentheses. Estimated marginal effects are reported in brackets. $* * *$ indicates significance at the $1 \%$ level, $* *$ at the $5 \%$ level, and $*$ at the $10 \%$ level.

\subsection{Logit Models - Fear of Rejection}

As a second step of our investigation, we test our hypothesis by employing logit models and we further corroborate our findings through a series of robustness checks carried out via Heckman selection models. More specifically, to estimate equation [1] we now employ the dummy Fear (already described in Section 3.2) as a dependent variable.

Results are reported in Table 4 and Table 5, where we employ Freedom from corruption and Control of corruption as proxies for corruption, respectively. Moreover, the regressions displayed in both Table 4 and Table 5 vary, among the different columns, because of the progressive inclusion of the country-level controls (Column 2 ), and the interaction term with the proxy of corruption (Column 3). The inclusion of the latter is aimed at reducing concerns that the self-refrain behavior of the small firms is rather driven by their structural and financial characteristics than by the discouragement effect of corruption. 
Table 4. Logit Model - with Freedom from Corruption

\begin{tabular}{llll}
\hline & $(1)$ & $(2)$ & $(3)$ \\
& Fear & Fear & Fear \\
\hline Small & $0.632^{* * *}$ & $0.634^{* * *}$ & 0.081 \\
Freedom from Corruption & $(0.09)$ & $(0.09)$ & $(0.30)$ \\
& $-0.067 * *$ & -0.049 & -0.055 \\
Small x Freedom from Corruption & $(0.03)$ & $(0.04)$ & $(0.04)$ \\
& & & $0.008^{* *}$ \\
GDP Growth & & $(0.00)$ & 0.081 \\
& & 0.081 & $(0.06)$ \\
Concentration & & $(0.06)$ & $-13.551^{*}$ \\
NPL & & $-13.519 *$ & $(7.98)$ \\
& & $(7.98)$ & $0.081^{* * *}$ \\
OMT & & $0.081^{* * *}$ & $(0.03)$ \\
& & $(0.03)$ & $-0.505^{* * *}$ \\
SAFE Controls & & $-0.507^{* * *}$ & $(0.16)$ \\
Pseudo R-squared & & $(0.16)$ & YES \\
\hline
\end{tabular}

Note: This table shows regression results of the logit model regarding the likelihood that small firms do not apply for bank loans for fear of rejection. The dependent variable (Fear) - as described in Section 3.2- is a dummy that equals one if a firm did not apply because of possible rejection, and zero otherwise. Small is a dummy that equals one if the firm has fewer than 50 employees, and zero otherwise. Though not showing, all the models include a wide set of firm-level characteristics. See Table A1 in the Appendix for all variable definitions and sources. All regressions use sampling weights that adjust the sample to be representative of the population. Additionally, all regressions include time and country dummies. Heteroskedasticity-robust standard errors, clustered at the country level, appear in parentheses. $* * *$ indicates significance at the $1 \%$ level, $* *$ at the $5 \%$ level, and $*$ at the $10 \%$ level.

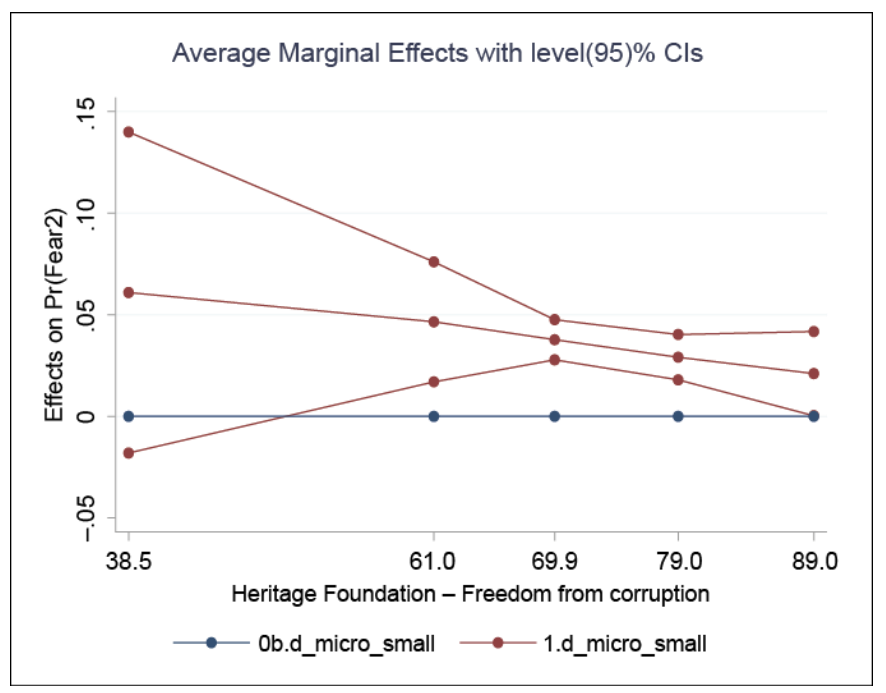

Figure 5. Marginal Effect of Small Firms Not Applying for Fear of Rejection for Different Levels of Corruption (as proxied by Freedom from Corruption)

The results from Table 4 highlight that - in line with the findings previously obtained with the multilogit analysis - small firms refrain from applying for bank loans for fear of rejection, as they anticipate a negative response from the lender. The variable Freedom from corruption presents a negative and significant sign suggesting that, when the level of corruption is lower, firms may experience a lower probability of self-restraint. Interestingly, the interaction between size and corruption shows a positive and significant sign. For this reason, we decide to plot the probability that a small firm does not apply for fear of rejection, for different levels of corruption (see Figure 
5). Figure 5 shows that the higher the freedom from corruption (i.e., the lower the corruption), the lower the probability that small firms will not apply for a bank loan for fear of seeing their application rejected. Put another way, the lower the corruption, the lower the share of discouraged borrowers.

We now try to corroborate our findings by employing a different proxy of corruption, namely Control of corruption. The results, reported in Table 5, are consistent with those presented in Table 4. Namely, we find that small firms refrain from applying for bank loans, and we also see that corruption influences their financing strategy.

Table 5. Logit Model - with Control of Corruption

\begin{tabular}{llll}
\hline & $(1)$ & $(2)$ & $(3)$ \\
& Fear & Fear & Fear \\
\hline Small & $0.627^{* * *}$ & $0.633^{* * *}$ & $0.409^{* * *}$ \\
Control of Corruption & $(0.09)$ & $(0.09)$ & $(0.13)$ \\
& -0.998 & -0.664 & -0.798 \\
Small x Control of Corruption & $(1.04)$ & $(0.70)$ & $(0.69)$ \\
& & & $0.176^{* *}$ \\
GDP Growth & & & $(0.08)$ \\
& & 0.056 \\
Concentration & & $(0.04)$ & $(0.04)$ \\
& & -12.582 & -12.622 \\
NPL & & $(8.67)$ & $(8.68)$ \\
OMT & & $0.106^{* * *}$ & $0.106^{* * *}$ \\
SAFE Controls & & $(0.04)$ & $(0.04)$ \\
Observations & & $-0.591 * * *$ & $-0.589^{* * *}$ \\
Pseudo R-squared & & $(0.15)$ & $(0.15)$ \\
\hline
\end{tabular}

Note: This table shows regression results of the logit model regarding the likelihood that small firms do not apply for bank loans for fear of rejection. The dependent variable (Fear) is a dummy that equals one if a firm did not apply because of possible rejection, and zero otherwise. Small is a dummy that equals one if the firm has fewer than 50 employees, and zero otherwise. Though not showing, all the models include a wide set of firm-level characteristics. See Table A1 in the Appendix for all variable definitions and sources. All regressions use sampling weights that adjust the sample to be representative of the population. Additionally, all regressions include time and country dummies. Heteroskedasticity-robust standard errors, clustered at the country level, appear in parentheses. $* * *$ indicates significance at the $1 \%$ level, $* *$ at the $5 \%$ level, and $*$ at the $10 \%$ level.

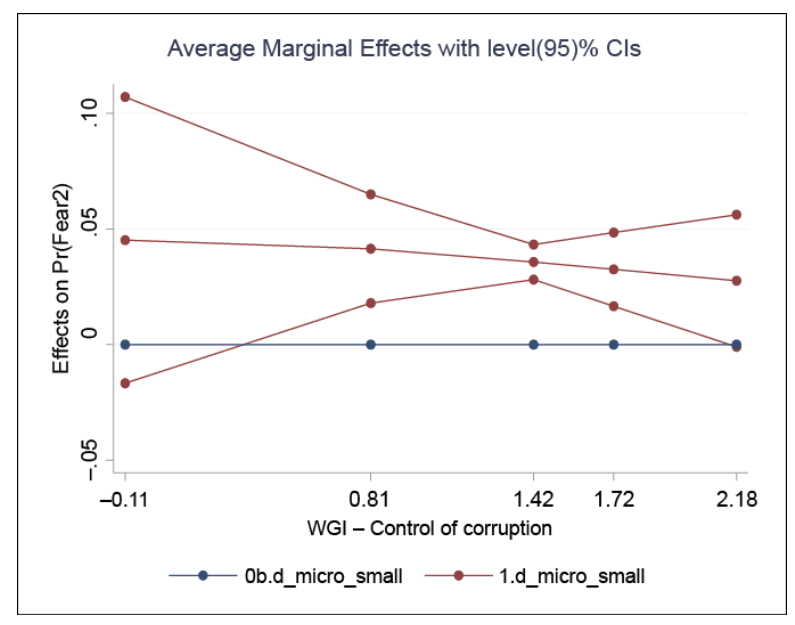

Figure 6. Marginal Effect of Small Firms Not Applying for Fear of Rejection for Different Levels of Corruption (as proxied by Control of Corruption)

As for the marginal effects, Figure 6 plots the probability that a small firm does not apply for fear of rejection, 
for different levels of corruption (as proxied by Control of corruption). The results - in this case too - show that the lower the degree of corruption, the lower the fear of rejection experienced by small firms.

\subsection{Robustness Checks: Heckman Selection Models}

In this section we present further robustness checks. Because the tests in Section 4.2 (i.e., logit models) have been conducted on a sample of firms that did not apply for bank loans (thereby excluding those who applied), one might raise concerns that our results are affected by a sample selection bias. To overcome this potential criticism, we re-estimate our models following the Heckman (1979) approach, which requires us to specify a selection equation that includes a set of variables affecting the possibility of observing the phenomenon but not the outcome itself. The results are displayed in Table 6 and Table 7 and corroborate our previous findings.

Table 6. Heckman Selection Model - with Freedom from Corruption

\begin{tabular}{|c|c|c|c|}
\hline & (1) & (2) & (3) \\
\hline & Fear & Fear & Fear \\
\hline \multicolumn{4}{|l|}{ Regression equation } \\
\hline \multirow[t]{2}{*}{ Small } & $0.027 * * *$ & $0.027 * * *$ & 0.003 \\
\hline & $(0.00)$ & $(0.00)$ & $(0.01)$ \\
\hline \multirow[t]{2}{*}{ Freedom from Corruption } & $-0.003 * * *$ & $-0.001 *$ & $-0.001 * *$ \\
\hline & $(0.00)$ & $(0.00)$ & $(0.00)$ \\
\hline \multirow[t]{2}{*}{ Small $\mathrm{x}$ Freedom from Corruption } & & & $0.000 * *$ \\
\hline & & & $(0.00)$ \\
\hline \multirow[t]{2}{*}{ GDP Growth } & & 0.001 & 0.001 \\
\hline & & $(0.00)$ & $(0.00)$ \\
\hline \multirow[t]{2}{*}{ Concentration } & & $-0.437 * * *$ & $-0.433 * * *$ \\
\hline & & $(0.13)$ & $(0.13)$ \\
\hline \multirow[t]{2}{*}{ NPL } & & $0.005 * * *$ & $0.005 * * *$ \\
\hline & & $(0.00)$ & $(0.00)$ \\
\hline \multirow[t]{2}{*}{ OMT } & & $-0.029 * * *$ & $-0.029 * * *$ \\
\hline & & $(0.01)$ & $(0.01)$ \\
\hline SAFE Controls & YES & YES & YES \\
\hline \multicolumn{4}{|l|}{ Selection equation } \\
\hline \multirow[t]{2}{*}{ Demand up } & $-1.364 * * *$ & $-1.364 * * *$ & $-1.364 * * *$ \\
\hline & $(0.01)$ & $(0.01)$ & $(0.01)$ \\
\hline \multirow[t]{2}{*}{ Lambda (Mills ratio) } & $0.216^{* * *}$ & $0.214 * * *$ & $0.214 * * *$ \\
\hline & $(0.01)$ & $(0.01)$ & $(0.01)$ \\
\hline Observations & 72,372 & 72,372 & 72,372 \\
\hline Prob> chi2 & 0 & 0 & 0 \\
\hline
\end{tabular}

Note: This table shows regression results of the Heckman selection model regarding the likelihood that small firms do not apply for bank loans for fear of rejection. The dependent variable (Fear) is a dummy that equals one if a firm did not apply because of possible rejection, and zero otherwise. Small is a dummy that equals one if the firm has fewer than 50 employees, and zero otherwise. Though not showing, all the models include a wide set of firm-level characteristics. See Table A1 in the Appendix for all variable definitions and sources. All regressions use sampling weights that adjust the sample to be representative of the population. Additionally, all regressions include time and country dummies. Heteroskedasticity-robust standard errors, clustered at the country level, appear in parentheses. *** indicates significance at the $1 \%$ level, ** at the 5\% level, and * at the $10 \%$ level. 
Table 7. Heckman Selection Model - with Control of Corruption

\begin{tabular}{|c|c|c|c|}
\hline & (1) & (2) & (3) \\
\hline & Fear & Fear & Fear \\
\hline \multicolumn{4}{|l|}{ Regression equation } \\
\hline \multirow[t]{2}{*}{ Small } & $0.027 * * *$ & $0.027 * * *$ & $0.017 * * *$ \\
\hline & $(0.00)$ & $(0.00)$ & $(0.01)$ \\
\hline \multirow[t]{2}{*}{ Control of Corruption } & $-0.042 * *$ & -0.019 & -0.025 \\
\hline & $(0.02)$ & $(0.02)$ & $(0.02)$ \\
\hline \multirow[t]{2}{*}{ Small x Control of Corruption } & & & $0.008 * *$ \\
\hline & & & $(0.00)$ \\
\hline \multirow[t]{2}{*}{ GDP Growth } & & 0.001 & 0.001 \\
\hline & & $(0.00)$ & $(0.00)$ \\
\hline \multirow[t]{2}{*}{ Concentration } & & $-0.363^{* * *}$ & $-0.362 * * *$ \\
\hline & & $(0.12)$ & $(0.12)$ \\
\hline \multirow[t]{2}{*}{ NPL } & & $0.005^{* * *}$ & $0.005^{* * *}$ \\
\hline & & $(0.00)$ & $(0.00)$ \\
\hline \multirow[t]{2}{*}{ OMT } & & $-0.030 * * *$ & $-0.030 * * *$ \\
\hline & & $(0.01)$ & $(0.01)$ \\
\hline SAFE Controls & YES & YES & YES \\
\hline \multicolumn{4}{|l|}{ Selection equation } \\
\hline \multirow[t]{2}{*}{ Demand up } & $-1.364 * * *$ & $-1.364 * * *$ & $-1.364 * * *$ \\
\hline & $(0.01)$ & $(0.01)$ & $(0.01)$ \\
\hline \multirow[t]{2}{*}{ Lambda (Mills ratio) } & $0.216^{* * *}$ & $0.214 * * *$ & $0.214 * * *$ \\
\hline & $(0.01)$ & $(0.01)$ & $(0.01)$ \\
\hline Observations & 72,372 & 72,372 & 72,372 \\
\hline Prob> chi2 & 0 & 0 & 0 \\
\hline
\end{tabular}

Note: This table shows regression results of the Heckman selection model regarding the likelihood that small firms do not apply for bank loans for fear of rejection. The dependent variable (Fear) is a dummy that equals one if a firm did not apply because of possible rejection, and zero otherwise. Small is a dummy that equals one if the firm has fewer than 50 employees, and zero otherwise. Though not showing, all the models include a wide set of firm-level characteristics. See Table A1 in the Appendix for all variable definitions and sources. All regressions use sampling weights that adjust the sample to be representative of the population. Additionally, all regressions include time and country dummies. Heteroskedasticity-robust standard errors, clustered at the country level, appear in parentheses. $* * *$ indicates significance at the $1 \%$ level, ** at the 5\% level, and * at the $10 \%$ level.

\subsection{Further Analysis: Multinomial Logit Models - Sample Split by Corruption}

In this section we discuss the results obtained when estimating our equation [1] for two subsamples that we get by splitting the initial data set into low- and high-corruption countries. Indeed, after having calculated the mean level of Freedom from corruption across the full sample, we are able to build two distinct clusters that distinguish the low-corruption countries (observations above the mean) from the high-corruption ones (observations below the mean). ${ }^{4}$ The results of our estimations are tabulated in Table 8.

\footnotetext{
${ }^{4}$ For the sake of clarity, the high-corruption countries are Greece, Italy, Portugal, and Spain. The low-corruption nations are Austria, Belgium, Finland, France, Germany, Ireland, and the Netherlands. In this regard, see Figure 4 that shows the degree of freedom from corruption by country.
} 
Table 8. Bank Loan Applications - Multinomial Logit Model - Sample Split by Corruption

\begin{tabular}{|c|c|c|c|c|}
\hline & (1) & (2) & (3) & (4) \\
\hline & Applied & $\begin{array}{l}\text { Did_not_apply } \\
\text { _fear }\end{array}$ & $\begin{array}{l}\text { Did_not_apply } \\
\text { _suff }\end{array}$ & $\begin{array}{l}\text { Did_not_apply } \\
\text { _other }\end{array}$ \\
\hline \multicolumn{5}{|c|}{ Panel A: Low corruption } \\
\hline \multirow[t]{3}{*}{ Small } & (base) & $1.061 * * *$ & $0.333^{* *}$ & $0.543^{* * *}$ \\
\hline & & $(0.09)$ & $(0.13)$ & $(0.12)$ \\
\hline & & {$[0.062]$} & & \\
\hline SAFE Controls & YES & YES & YES & YES \\
\hline Observations & 36,907 & 36,907 & 36,907 & 36,907 \\
\hline Pseudo R-squared & 0.0677 & 0.0677 & 0.0677 & 0.0677 \\
\hline \multicolumn{5}{|c|}{ Panel B: High corruption } \\
\hline \multirow[t]{3}{*}{ Small } & (base) & $0.947 * * *$ & $0.461 * * *$ & $0.574 * * *$ \\
\hline & & $(0.17)$ & $(0.03)$ & $(0.06)$ \\
\hline & & {$[0.074]$} & & \\
\hline SAFE Controls & YES & YES & YES & YES \\
\hline Observations & 25,739 & 25,739 & 25,739 & 25,739 \\
\hline Pseudo R-squared & 0.0713 & 0.0713 & 0.0713 & 0.0713 \\
\hline
\end{tabular}

Note: This table shows regression results of the multinomial logit model regarding the likelihood that small firms do not apply for bank loans. The dependent variable -as described in Section 3.2 - equals 1/2/3/4 if a firm applied/did not apply because of possible rejection/did not apply because of sufficient internal funds/did not apply for other reasons during the past six months, respectively. Small is a dummy that equals one if the firm has fewer than 50 employees, and zero otherwise. Table A(B) reports regressions on a subsample of firms chartered in low- (high-) corruption countries. Though not showing, both specifications include a wide set of firm-level characteristics. See Table A1 in the Appendix for all variable definitions and sources. All regressions use sampling weights that adjust the sample to be representative of the population. Additionally, all regressions include time and country dummies. Heteroskedasticity-robust standard errors, clustered at the country level, appear in parentheses. Estimated marginal effects are reported in brackets. $* * *$ indicates significance at the $1 \%$ level, ** at the 5\% level, and * at the $10 \%$ level.

More specifically, Table 8 presents the coefficients and the marginal effects of our key variable small firms (Small) in the economies characterized by lower (Panel A) and higher (Panel B) levels of corruption. In both cases, the results in Column 2 confirm the evidence previously found in the overall sample - namely, small firms (in both regional clusters) are more likely not to apply for fear of rejection than larger enterprises. In particular, small firms are $7.4 \%$ (6.2\%) more likely than their larger peers to refrain from applying for a bank loan for fear of rejection in high- (low-) corruption economies.

\section{Conclusions}

The global financial crisis worsened the conditions of access to the credit market for enterprises in Europe. Therefore, improving access to bank credit, especially for MSMEs, becomes important to safeguard the survi val and de velopment of their businesses. In this paper, we have attempted to assess how the level of corruption combined with several economic and financial features - affected the access to credit for MSMEs during our observed period.

Specifically, our research hypothesis aims at testing whether a more corrupt environment affects MSMEs' expectations on the bank-firm relationship and in turn the probability to self-refrain from applying to bank loans more than larger firms. This may be the case because MSMEs anticipate more difficulties in having access to credit.

We employ different specifications. First we estimate the probability of self restraint for MSMEs, compared to larger firms, after controlling for alternative measures of corruption, as well as for a set of macro firm-invariant indicators and standard and financial micro features. Second, we focus on the phenomenon of the discouraged borrowers assessing how the level of corruption might affect their demand for credit. Additionally, in order to limit the source of bias between small firms, credit access and corruption, we interact small firms with the corruption measures. Finally, to corroborate our results and avoid the selection bias, we propose several econometric strategies and different subsamples of observations.

Overall, our results show that the level of corruption seems to affect the behavior of small firms in the credit 
market since they are more likely to refrain - especially in high-corruption countries - from applying for bank loans than their larger peers. Interestingly, results indicate that small firms chartered in high-corruption economies are more likely to refrain from applying for loans (more than 7.4\%) than small firms located in low-corruption ones (about 6.2\%).

Results turn to be robust to different specifications and econometric methodologies. Nevertheless, we are aware that - although we have tried our best to limit the presence of bias in our estimates - given the qualitative nature of the SAFE dataset, missing information might still play a role in explaining the relationship between bank access, small firms and the level of corruption. Our results seem to suggest that policymakers should intervene in most corrupt countries in order to limit the aforementioned negative spillovers and to support the access to bank credit for small firms.

\section{References}

Acemoglu, D., \& Thierry, V. (1998). Property rights, corruption and the allocation of talent: a general equilibrium approach. Economic Journal, 108(450), 1381-1403. https://doi.org/10.1111/1468-0297.00347

Andvig, J. C., \& Moene, K. O. (1990). How corruption may corrupt. Journal of Economic Behavior and Organization, 13, 63-76. https://doi.org/10.1016/0167-2681(90)90053-G

Ayadi, R., \& Gadi, S. (2013). Access by SMEs to Finance in the Southern and Eastern Mediterranean: What Role for Credit Guarantee Schemes. European Commission, MEDPRO Technical Report No. 35.

Badoer, D. C., \& James, C M. (2016). The determinants of long-term corporate debt issuances. The Journal of Finance, 71(1), 457-492. https://doi.org/10.1111/jofi.12264

Bhagwati, J. (1982). Directly unproductive profit-seeking (DUP) activities. Journal of Political Economy, 90, 988-1002. https://doi.org/10.1086/261104

Blackburn, K., \&Sarmah, R. (2008). Corruption, development and demography. Economics of Governance, 9 , 341-362. https://doi.org/10.1007/s10101-007-0045-0

Campos, N., Estrin, S., \& Proto, E. (2010). Corruption as a Barrier to Entry: Theory and Evidence. CEPR Discussion Paper n. 8061.

Cavalluzzo, K. S., Cavalluzzo, L. C., \& Wolken, J. D. (2002). Competition, small business financing, and discrimination: Evidence from a new survey. Journal of Business, 75(4), 641-679. https://doi.org/10.1086/341638

Cowan, K., Drexler, A., \& Yañez, Á. (2015). The effect of credit guarantees on credit availability and delinquency rates. Journal of Banking and Finance, 59, 98-110. https://doi.org/10.1016/j.jbankfin.2015.04.024

Demirguc-Kunt, A., Klapper, L., \& Singer, D. (2013). Financial Inclusion and Legal Discrimination against Women: Evidence from Developing Countries. Policy Research Working Paper 6616. World Bank, Washington, DC. https://doi.org/10.1596/1813-9450-6416

Dimant, E., \& Tosato, G. (2017). Causes and Effects of Corruption: What has Past Decade's Research Taught us? A Survey. MPRAPaper No. 76445.

Djankov, S., La Porta, R., Lopez-de-Silanes, F., \& Shleifer, A. (2008). The law and economics of self-dealing. Journal of Financial Economics, 88, 430-465. https://doi.org/10.1016/j.jfineco.2007.02.007

EIF, (2016). European Small Business Finance Outlook. Working Paper No. 2016/37.

Ferrando, A., Popov, A., \& Udell, G. F. (2017). Sovereign Stress and SMEs' Access to Finance: Evidence from the ECB's SAFE Survey. Journal of Banking and Finance. https://doi.org/10.1016/j.jbankfin.2017.04.012

Galli, E., Mascia, D. V., \& Rossi, S. P. S. (2017). Legal-institutional environment, social capital and the cost of bank financing for SMEs: Evidence from the euro area. In SPS Rossi (ed.) Access to Bank Credit and SME Financing, Palgrave Macmillan Studies in Banking and Financial Institutions, London. https://doi.org/10.1007/978-3-319-41363-1_3

Gbetnkom, D. (2012). Corruption and small and medium-sized enterprise growth in Cameroon. Mimeo.

Guiso, L., Sapienza, P., \& Zingales, L. (2004). The role of social capital in financial development. American Economic Review, 94(3), 526-556. https://doi.org/10.1257/0002828041464498

Gutmann, J., Padovano, F., \& Voigt, S. (2014). Perception vs. experience: How to explain differences in corruption measures using microdata? Mimeo. 
Gyimah-Brempong, K. (2002). Corruption, economic growth, and income inequality in Africa. Economics of Governance, 3, 183-209. https://doi.org/10.1007/s 101010200045

Hall, R. E., \& Jones, C. (1999). Why do some countries produce so much more output per worker than others? Quarterly Journal of Economics, 114, 83-116. https://doi.org/10.1162/003355399555954

Heckman, J. J. (1979). Sample selection bias as a specification error. Econometrica, 47(1), 153-161. https://doi.org/10.2307/1912352

Hunt, J. (2005). Why are some public officials more corrupt than others? In S Rose-Ackerman (ed.) The Handbook of Corruption. Edward Elgar Publishers, Cheltenham, UK and Northampton, US. https://doi.org/10.3386/w11595

Hunt, J., \& Laszlo, S. (2005). Bribery: Who Pays, Who Refuses, What are the Payoffs? Working Paper No. 11635, NBER.

Kaufmann, D. (2005). Myths and realities of governance and corruption. http://ssrn.com/abstract $=829244$ (accessed 12 June 2017).

Keefer, S., \& Knack, P. (1997). Does social capital have an economic payoff? A cross-country investigation. The Quarterly Journal of Economics, 112(4), 1251-1288. https://doi.org/10.1162/003355300555475

Klitgaard, R. (1988). Controlling corruption, Berkeley, CA: University of California Press.

Kremp, E., \& Se vestre, P. (2013). Did the crisis induce credit rationing for French SMEs? Journal of Banking and Finance, 37(10), 3757-3772. https://doi.org/10.1016/j.jbankfin.2013.05.028

La Porta, R., Lopez De-Silanes, F., \& Shleifer, A., et al. (1997). Legal determinants of external finance. The Journal of Finance, 7(3), 1131-1150. https://doi.org/10.1111/j.1540-6261.1997.tb02727.x

La Porta, R., Lopez-de-Silanes, F., Shleifer, A., \& Vishny, R. W. (1999). The quality of government. Journal of Economics, Law and Organization, 15(1), 222-279. https://doi.org/10.1093/jleo/15.1.222

Li, H., Xu, C. L., \& Zou, H. (2000). Corruption, income distribution and growth. Economics and Politics, 12, 155-182. https://doi.org/10.1111/1468-0343.00073

Lui, F. T. (1985). An equilibrium queuing model of bribery. Journal of Political Economy, 93,760-781. https://doi.org/10.1086/261329

Mauro, P. (1995). Corruption and growth. Quarterly. Journal of Economics, 110(3), 681-712. https://doi.org/10.2307/2946696

Mistrulli, P. E., \& Vacca, V. (2014). Social capital and the cost of credit in a crisis. Bank of Italy. Mimeo

Moro, A., \& Fink, M. (2013). Loan managers' trust and credit access for SMEs. Journal of Banking and Finance, 37, 927-936. https://doi.org/10.1016/j.jbankfin.2012.10.023

Moro, A., Maresch, D., \& Ferrando, A. (2016). Creditor protection, judicial enforcement and credit access. The European Journal of Finance. https://doi.org/10.1080/1351847X.2016.1216871

Myrdal, G. (1989). Corruption: Its causes and effects, in A J Heidenheimer, M Johnston and V T LeVine (eds) Political Corruption: A Handbook. Transaction Books, New Brunswick, NJ.

Öztürk, B., \& Mrkaic, M. (2014). SMSs’ Access to Finance in the Euro Area: What Helps of Hampers? IMF WP $14 / 78$.

Popov, A., \& Udell, G. F. (2012). Cross-border banking, credit access, and the financial crisis. Journal of International Economics, 87,147-161. https://doi.org/10.1016/j.jinteco.2012.01.008

Popov, A., \& Van Horen, N. (2015). Exporting sovereign stress: Evidence from syndicated bank lending during the euro area sovereign debt crisis. Review of Finance, 19, 1825-1866. https://doi.org/10.1093/rof/rfu046

Qian, J., \& Strahan, P. E. (2007). How laws and institutions shape financial contracts: The case of bank loans. Journal of Finance, 62(6), 2803-2834. https://doi.org/10.1111/j.1540-6261.2007.01293.x

Rose-Ackerman, S. (1975). The economics of corruption. Journal of Public Economics, 4, 187-203. https://doi.org/10.1016/0047-2727(75)90017-1

Seker, M., \& Yang, J. S. (2012). How Bribery Distorts Firm Growth. Differences by Firm Attributes. World Bank. https://doi.org/10.1596/1813-9450-6046

Shleifer, A., \& Vishny, R. W. (1993). Corruption. Quarterly Journal of Economics, CVIII, 599-617. 
https://doi.org/10.2307/2118402

Svensson, J. (2003). Who must pay bribes and how much? Evidence from a cross-section of firms. Quarterly Journal of Economics, 118(1), 207-230. https://doi.org/10.1162/00335530360535180

Tanzi, V., \& Davoodi, H. R. (2002). Corruption, growth, and public finances, in G T Abed and S Gupta (eds) Governance, Corruption, and Economic Performance. IMF Washington, DC.

Uzzi, B. (1999). Embeddedness in the making of financial capital: How Social relations and the networks benefit firms seeking financing. American Sociological Review, 64, 481-505. https://doi.org/10.2307/2657252

Vermoesen, V., Deloof, M., \& Laveren, E. (2013). Long-term debt maturity and financing constraints of SMEs during the global financial crisis. Small Business Economics, 41, 433-448. https://doi.org/10.1007/s11187-012-9435-y

Vos, E., Yeh, A. J., Carter, S., \& Tagg, S. (2007). The happy story of small business financing. Journal of Banking and Finance, 31, 2648-2672. https://doi.org/10.1016/j.jbankfin.2006.09.011

World Bank. (2007). Investment Climate Survey. In UNIDO/UNODC Corruption Prevention to Foster Small and Medium-sized Enterprise Development, Vienna.

World Bank. (various years). The Business Environment and Enterprise Performance Survey, various years. 


\section{APPENDIX A}

Table A1. Variable descriptions and sources

\begin{tabular}{|c|c|c|}
\hline Variables & Description & Source \\
\hline \multicolumn{3}{|l|}{$\begin{array}{l}\text { Dependent } \\
\text { variables }\end{array}$} \\
\hline $\begin{array}{l}\text { Bank loans } \\
\text { application }\end{array}$ & $\begin{array}{l}\text { Variable that equals one/two/three/four if a firm applied/did not apply because of } \\
\text { possible rejection/did not apply because of sufficient internal funds/did not apply for } \\
\text { other reasons during the past six months, respectively. }\end{array}$ & ECB: SAFE \\
\hline Fear & $\begin{array}{l}\text { Variable that equals one if a firm did not apply for a bank loan because of possible } \\
\text { rejection during the past six months. }\end{array}$ & ECB: SAFE \\
\hline \multicolumn{3}{|c|}{ 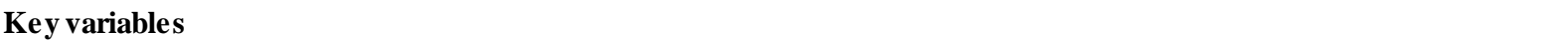 } \\
\hline Small firms & Dummy variable that equals one if the firm has fewer than 50 employees. & ECB: SAFE \\
\hline \multicolumn{3}{|l|}{$\begin{array}{l}\text { Country-level } \\
\text { controls }\end{array}$} \\
\hline $\begin{array}{l}\text { Freedom } \\
\text { from corruption }\end{array}$ & $\begin{array}{l}\text { The higher the level of corruption, the lower the level of overall economic freedom } \\
\text { and the lower a country's score. }\end{array}$ & $\begin{array}{l}\text { Heritage } \\
\text { Foundation }\end{array}$ \\
\hline $\begin{array}{l}\text { Control } \\
\text { of corruption }\end{array}$ & The higher the level of corruption, the lower a country's score. & $\begin{array}{l}\text { World Bank: } \\
\text { WGI }\end{array}$ \\
\hline GDP Growth & $\begin{array}{l}\text { The annual growth rate of real GDP based on averages of quarterly data for each } \\
\text { survey round. }\end{array}$ & OECD \\
\hline Concentration & The Herfindahl index (HI) of total assets concentration (for the banking sector). & $\begin{array}{l}\text { ECB: Data } \\
\text { Warehouse }\end{array}$ \\
\hline NPL & The ratio of bank nonperforming loans to total gross loans. & World Bank \\
\hline OMT & $\begin{array}{l}\text { Dummy variable that equals one from the year of announcement (2012) of the } \\
\text { Outright Monetary Transactions (OMT) program. }\end{array}$ & $\begin{array}{l}\text { Our } \\
\text { calculation }\end{array}$ \\
\hline \multicolumn{3}{|l|}{$\begin{array}{l}\text { Firm-level } \\
\text { controls }\end{array}$} \\
\hline Profit up & $\begin{array}{l}\text { Dummy variable that equals one if a firm experienced an increase of the net income } \\
\text { after taxes in the past six months. }\end{array}$ & ECB: SAFE \\
\hline Profit down & $\begin{array}{l}\text { Dummy variable that equals one if a firm experienced a decrease of the net income } \\
\text { after taxes in the past six months. }\end{array}$ & ECB: SAFE \\
\hline $\begin{array}{l}\text { Creditw orthiness } \\
\text { up }\end{array}$ & $\begin{array}{l}\text { Dummy variable that equals one if the firm's credit history improved in the past six } \\
\text { months. }\end{array}$ & ECB: SAFE \\
\hline $\begin{array}{l}\text { Creditw orthiness } \\
\text { down }\end{array}$ & $\begin{array}{l}\text { Dummy variable that equals one if the firm's credit history worsened in the past six } \\
\text { months. }\end{array}$ & ECB: SAFE \\
\hline Capital up & $\begin{array}{l}\text { Dummy variable that equals one if a firm's own capital has improved in the past six } \\
\text { months. }\end{array}$ & ECB: SAFE \\
\hline Capital down & $\begin{array}{l}\text { Dummy variable that equals one if a firm's own capital has deteriorated in the past } \\
\text { six months. }\end{array}$ & ECB: SAFE \\
\hline Leverage up & $\begin{array}{l}\text { Dummy variable that equals one if a firm experienced an increase in the } \\
\text { debt-to-assets ratio in the past six months. }\end{array}$ & ECB: SAFE \\
\hline Leverage down & $\begin{array}{l}\text { Dummy variable that equals one if a firm experienced a decrease in the debt-to-assets } \\
\text { ratio in the past six months. }\end{array}$ & ECB: SAFE \\
\hline Demand up & $\begin{array}{l}\text { Dummy variable that equals one if a firm's needs for a bank loan increased in the past } \\
\text { six months. }\end{array}$ & ECB: SAFE \\
\hline Demand down & $\begin{array}{l}\text { Dummy variable that equals one if a firm's needs for a bank loan decreased in the } \\
\text { past six months. }\end{array}$ & ECB: SAFE \\
\hline Very recent & Dummy variable that equals one if the firm is less than 2 years old. & ECB: SAFE \\
\hline Recent & Dummy variable that equals one if the firm is between 2 and 5 years old. & ECB: SAFE \\
\hline Old & Dummy variable that equals one if the firm is between 5 and 10 years old. & ECB: SAFE \\
\hline Construction & Dummy variable that equals one if the firm's main activity is construction. & ECB: SAFE \\
\hline Manufacturing & Dummy variable that equals one if the firm's main activity is manufacturing. & ECB: SAFE \\
\hline Wholesale/Retail & $\begin{array}{l}\text { Dummy variable that equals one if the firm's main activity is wholesale or retail } \\
\text { trade. }\end{array}$ & ECB: SAFE \\
\hline
\end{tabular}

\section{Copyrights}

Copyright for this article is retained by the Asian Development Bank Institute (ADBI), Tokyo.

This is an open-access article distributed under the terms and conditions of the Creative Commons Attribution license (http://creativecommons.org/licenses/by/4.0/). 